Годишњак Филозофског факултета у Новом Саду, Кюига ХХХVII (2012)

Михайло Фейса

Новосадски универзитет, Филозофски факултет

fejsam@eunet.rs, fejsam@gmail.com
УДК 323.1(=161.2)(497.113):81

Оригиналан научни рад

\title{
РУСКИ ЯЗИК У СЛАВЯНСКИМ ЯЗИЧНИМ ПРОСТОРУ
}

Бачко-сримски Руснаци / Русини представяю доказ же длуготирваце егзистованє єдней малочисленей заєднїци цалком можлїве лєм кед держава витвори одвитуюци условия. Сербия обезпечела високи ступень гаранцийох же меншински права у обласцох образованя, култури, информованя и урядового хаснованя язика и писма, буду, по значни уровень, почитовани.

Руснациприпадаю карпаторусинскому/рускомународу, автохтоней славянскей популациї централноевропско-карпатского региона, подзелєного з гранїцами України, Польскей, Словацкей, Мадярскей, Румуниї, Ческей републики и Молдавиї. Виводзаци заключенє по стандардних критериюмох одредзованя припадносци гу восточней, заходней и южней групи славянских язикох, автор заключує же руски язик дзелї характеристики $30 з$ заходнославянскима, хтори и преовладую, восточнославянскима та и южнославянскима язиками.

Ключни слова: Руснаци / Русини, руски язик, меншински язики, лингвистични критериюми.

Бачко-сримски Руснаци / Русини припадаю карпаторусинскому / рускому народу, автохтоней славянскей популациї централноевропско-карпатского региона, подзелєного з гранїцами України, Польскей, Словацкей, Мадярскей, Румуниї, Ческей републики и Молдавиї. Їх националне мено повязує их 303 востоком, прето же Рус (Русь) була назва териториї велькей стредньовиковней держави зоз центром у Києве. Велї назви з хторима ше карпатски Русини наволовали або з хторима их наволовали други - як напр. Карпато-Русин, Карпато-Рус, Угро-Русин, Рутен, Руснак, Рушняк итд. шицки ше одноша на жридлову и традиционалну вязу зоз восточнославянским народом Руси.

Виками Руснаци жили у гранїцох Мадярского кральовства. Жили у сиверовосточних мадярских жупанийох, точнєйше у Земплину, Шаришу, 
Абауй-Торни, Боршоду, Саболчу, Ужу, Угочи, Марамарошу и Гемеру (Fejsa, 2000; Фејса, 2010). Векшина $з$ тих жупанийох находзи ше нєшка у восточней Словацкей, а други у Мадярскей, України и Румуниї. Пред коло 260 роками групи Руснацох почали ше селїц зоз свойого отечества у Карпатских горох на юг до Сриму и Бачки, хтори ше нєшка находза у Войводини у Сербиї и у Восточней Славониї у Горватскей.

По пораженю и поцагованю Отоманскей империї з Бачки, Сриму и Банату 1699. року, австроугорским власцом требало вецей жительства на югу своєй держави та побудзовали на колонизацию Нємцох, Мадярох, Словакох и других, як и Руснацох (Gavrilović, 1977: 153). То причина прецо и предком войводянских Руснацох, гражданом шлєбодного статуса у Габсбургскей монархиї („,Ruthenus Libertinus“, як их наволовали) и грекокатолїцкей (униятскей) вири, у вкупним числу од коло 2.000 , допущене же би ше, по контракту з державнима власцами, населєли до „dessolata possessio Keresztur“ и места Коцур, хторе нєдалєко, у централней Бачки стредком XVIII вика (Хорњак, 2006: 25).

Присельованє до нового краю почало дзешка медзи 1743. и 1746. роком. Рок 1745. вжати як рок урядового насельованя Руснацох до Бачки з оглядом же 17. януара 1745. Франц Йозеф де Редл, совитнїк царици Мариї Терезиї и администратор Бачкого державного округу у Сомбору, подписал перши официйни документ - контракт о насельованю 200 руских, грекокатолїцких фамелийох на пустару Вельки Керестур. Контракт о насельованю Руснацох до Коцура подписани 1763. року (Лабош, 1979: 77). Евидентне же Руснаци були населєни до тих крайох под истима або подобнима условиями як и други народи (окрем Нємцох хтори мали найвигоднєйши условия насельованя). Значне визначиц же Руснаци були грекокатолїки и же то представяло єдну зоз причинох прецо им було дошлєбодзене населїц ше у южних часцох Австро-Угорскей

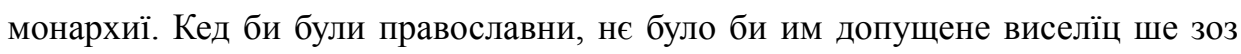
сиверних жупанийох.

У новим швеце приселєнци будовали хижи, обєкти за газдованє, церкви, школи и други явни институциї.

Рускокерестурска парохия основана 1751. року, а основна школа у Руским Керестуре почала робиц 1753. року. Перша грекокатолїцка церква у Коцуре збудована 1765. року. Рускокерестурска и коцурска парохия були 
уключени до Крижевского владичества за грекокатолїкох 1777. року. Пред тим парохиї були часци Калочскей католїцкей архиепископиї. Руснаци постали унияти (грекокатолїки од 1772. року) з Брестску (1596) и Ужгородску (1646) унию.

Як ше руске жительство 3 часом звекшовало, у глєданю роботи и лєпшого живота, велї ше, починаюци з конца XIX вика, виселєли з Руского Керестура и Коцура до Кули, Вербасу, Нового Саду и Дюрдьова у Бачки, до Шиду и Сримскей Митровици у Сриму (у терашнєй Сербиї), до Славониї и локалитетох коло Вуковару и рики Сави (у терашнєй Горватскей) и прейг Атлантского океану до Зєдинєних Америцких Державох и Канади.

Од часу кед ше перши Руснаци приселєли до тих крайох та по Першу шветову войну, вони доминантно були фармере. Їх ремеселнїки були организовани до еснафох, а священїкох и учительох було барз мало. 3 часом Руснаци напредовали у економским, националним и културним живоце. Поспишело им ше очувац свой идентитет. Формовали свой язик и подзвигли го на одредзени уровень же би го могли хасновац у друкованю кнїжкох. Перша кнїжка на руским язику Идилски венєц 3 мойого валалу Гавриїла Костельника, хтора публикована 1904. року.

На концу Першей шветовей войни Австро-Угорска монархия ше розпадла. Шицки конари русинского народу, хтори по 1918. рок, существовали и розвивали ше у рамикох єдней держави, Габсбургскей монархиї, вецей нє були вєдно. Руснаци у Бачки мушели найсц свою власну драгу.

У Сербиї (або у Кральовини Сербох, Горватох и Словенцох, або, познєйше, у Кральовини Югославиї) Руснацом допущене формовац национални, културни институциї на основи колективних правох шицких националних меншинох, цо не бул случай у їх старим краю. Вони достали статус националней меншини славянского походзеня 1919. року, перши и, у периодзе з велїх рокох, єдини медзи своїма сонароднїками у Карпатским ареалу. То була подїя од значеня найвисшого ступня хтора трасовала драгу їх националного и културного розвою. У таких обставинох Руснаци чувствовали же сноване Руского народного просвитного дружтва, воланого Просвита, бул перши крочай зоз хторим вони манифестовали свойо намаганє гу нєзависному националному и културному животу. На сновательней схадзки, 2. юлия 1919. 
року у Новим Садзе, руска национална заєднїца ришела дзвигнуц свой народни язик (нє русийски або українски) на уровень литературного язика. По нєшка ше каждодньова руска бешеда хаснує у образованю, културним живоце и преси.

Остатнї даскельо роки Република Сербия превжала даскельо крочаї хтори без сумнїву одкриваю вельку усиловносц би ше унапредзел статус рускей меншини. Пред осем роками (2002) Покраїнски секретарият за предписаня, управу и национални заєднїци установел за кажду меншину цалком нову институцию - Национални совит за кажду меншину. Остатнї даскельо роки Република Сербия превжала даскельо крочаї хтори без сумнїву одкриваю вельку усиловносц би ше унапредзел статус рускей меншини. Пред дзешец роками Покраїнски секретарият за предписаня, управу и национални заєднїци установел за кажду меншину цалком нову институцию - Национални совит за кажду меншину. Национални совити, як найвисши органи меншинскей самоуправи у Републики Сербиї, оформени на основи Закона о защити правох и шлєбодох националних меншинох 2002. року у тедишнєй Союзней Републики Югославиї хтори верификовала Скупштина, а з организацийну и другу потримовку Министерства за людски и меншински права (Руснаци, 2009: 17). Главни обласци активносци Националного совита рускей националней меншини то култура, образованє, медиї и, генерално патраци, скоро шицко цо значне за руску меншину. Совит єдини легални представитель рускей меншини. Шицки руски институциї и организациї конкурую зоз своїма проєктами при розличних покраїнских секретариятох (за национални меншини, за образованє, за науку и технологийни розвой, за културу, за вирски заєднїци, за привреду и други) а НСРНМ одобрує або одбива їх финансованє з боку покраїнских власцох. Национални совит рускей националней меншини достава и периодични буджетски средства як зоз министерствох Републики Сербиї зоз Београду, так и зоз покраїнских / войводянских секретариятох за финансованє, у єдней розумней мири, цалей културней активносци.

Року 2006. прилапени нови Устав и право на вибор националних совитох конституционализоване. Устав Републики Сербиї зоз 2006. року гарантує у члену 75. колективни меншински права на основи хторих припаднїки националних меншинох, нєпостредно або прейг своїх представнїкох, участвую у одлучованю або сами одлучую о поєдинєчних питаньох вязаних за свою културу, образованє, 
информованє и урядове хаснованє язикох и писмох, у складу зоз Законом. Устав уключує шицки релевантни медзинародни документи хтори ше одноша на меншини.

Припаднїки рускей меншини маю право образовац ше на мацеринским язику и нащивйовац годзини хтори ше фокусую на историю и културу меншини, a, источасно, паралелна настава на сербским язику обовязна.

Припаднїком рускей меншини оможлївене хасновац свой язик урядово у општини або населєню у хторим творя 15 \% локалного жительства. Уставни закон обезпечує и урядове хаснованє руского язика у судских поступкох, праве як и у виберанкових материялох. Рускей меншини дате право же би на своїм язику могла виписовац назви улїцох або других географских местох. У обласцох у хторих руска меншина твори по 15 \% локалного жительства законски предписаня ше обявюю на руским язику.

Сдна з уставних одредбох хтора заслужує окремну увагу то гевта хтора оможлївює членом националних меншинох же би шлєбодно запровадзовали и отримовали одношеня $30 з$ легалнима субєктами хтори пребуваю у странских державох, $з о з$ гевтима 303 хторима маю даяки колективни, културни, язични або вирски подобносци.

Держава ше обовязує же будзе финансовац главни културни активносци хтори организую припаднїки єдней националней меншини. За финансованє културних проєктох организаторе ше стимулую же би финансийни средства вимагали од приватних и державних организацийох и инситуцийох хтори ше находза у иножемстве.

Нєшка ше найширша културна активносц рускей националней заєднїци витворює у контексту коло двацец нєполитичних, културно-просвитнихуметнїцких организацийох и институцийох. Єст, иншак, коло двацец пейц традицийни културни фестивали / манифестациї.

Сумираюци период по початок дзеведзешатих рокох прешлого вика, Мирон Жирош наводзи 14 предпоставки (фактори) хтори, по нїм, приведли до финалного стану - егзистованя малей популациї свидомих Руснацох, утвердзованя їх националного язика и його подзвигованя на уровень 14 . славянского язика, узретосци рускей литератури, новинарства, фолклора и театра. Жирош видзелєл щлїдуюци фактори (Жирош, 1998: 463): 1. 
существованє двох руских центрох - Керестура и Коцура; 2. ясне припознаванє припаданя гу Русином Закарпатскей обласци; 3. моцне унапряменє на „триманє вєдно" медзи странцами; 4. Грекокатолїцка церква и чуванє националного идентитета; 5. руска школа; 6. стаємни контакти зоз Горнїцу (зоз карпатским отечеством, зоз бувшима Горнїма жемами Австро-Угорскей); 7. обезпечованє кнїжкох и друкарнї зоз Горнїци; 8. образованє рускей интелигенциї; 9. чуванє традицийох и националних обичайох (напр. церковних шветох - Крачуна, Велькей ноци, Кирбая), рускей свадзби и явного живота; 10. снованє Руского народного просвитного дружтва; 11. нове обновйованє, повойнови розвой од 1945. по 1990. рок; 12. улога Дружтва за руски язик и литературу; 13. Фестивал култури Червена ружа; 14. Драмски мемориял Петра Ризнича Дядї и Руски аматерски театер Дядя.

Маюци у оглядзе случованя у рускей националней заєднїци, на концу першей децениї 21. вика, Жирошова анализа би могла буц преширена 303 найменсй ещи дзешец факторами хтори без сумнїву доприноша существованю малей популациї свидомих Руснацох. Ми видзелєли шлїдуюци фактори: 1. Национални совит рускей националней меншини; 2. Завод за културу войводянских Руснацох; 3. Руски народни театер Петро Ризнич Дядя; 4. Апостолски егзархат за грекокатолїкох у Сербиї и Чарней Гори; 5. Образовна вертикала на руским язику; 6. Рижнородна видавательна активносц; 7. Електронски медиї; 8. Нови културни организациї и манифестациї; 9. Револуционерни пременки у Карпатским ареалу; 10. Вигодни медзинародни обставини. Кажди з наведзених факторох обробени у монографиї Нова Србија и њена русинска мањина / Нова Сербия и єй руска меншина / The New Serbia And Its Ruthenian Minority (Фејса, 2010), а з тей нагоди затримаме ше на пиятим фактору - образовней вертикали.

Яшелька, предлужене пребуванє и воспитни групи за пририхтованє дзецох до школи существую у Руским Керестуре. Воспитни групи у хторих ше дзеци пририхтую за школу на руским язику и предлужене пребуванє за предшколски дзеци егзистую у Коцуре и Дюрдьове. У стредкох у котрих нє постої можлївосц организованя порядних воспитних групох на руским язику, руски ше виучує як окремни предмет хтори ше вола Пестованє руского язика 3 елементами националней култури. Таки воспитни групи организовани у Кули, 
Новим Садзе и Вербаше, а планує ше организовац пестованє руского язика и у рамикох предшколских оддзелєньох у Бачинцох, Беркасове, Бикич Долу и Шиду (Руснаци, 2009: 25-26).

По Закону, руским дзецом цо ходза до основних школох у гевтих войводянских општинох и местох дзе жиє значни процент Руснацох (по 15 \%) оможлївени три годзини тижньово на їх мацеринским язику. Сербски язик (три годзини тижньово) и два странски язики (перши странски язик од 1. класи, други странски язик од 5. класи - два годзини тижньово) винїмки и обовязни су.

Попри порядней настави (шицки предмети) на руским язику од 1. по 8. класу у Руским Керестуре, Коцуре и Дюрдьове, у других руских стредкох дзе пре мале число школярох нєт можлївосци организованя порядней настави на руским язику организує ше виучованє руского язика зоз елементами националней култури. Предмет виборни и заступени є зоз двома годзинами тижньово. Вон заступени у Бачкей Тополї, Господїнцох, Коцуре, Кули, Нови Садзе, Новим Орахове, Петроварадину, Савиним Селу, Сримскей Каменїци, Сримскей Митровици, Суботици, Ветернику, Вербаше и у Шиду зоз окремнима оддзелєнями у Бачинцох, Беркасове и Бикич Долу. Вкупне число местох доходзи по 16, а вецей як 330 школяре облапени з нїм (Руснаци, 2009: 27). Общи тренд же ше число школярох у школох зоз порядну наставу зменшує, а число

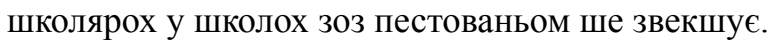

Основне образованє на руским язику обовязне и безплатне. Нєобходне минималне число школярох за организованє класи 15 , алє зоз допущеньом Министерства просвити можлїве организовац класу и за менше число од 15 .

Моментално нєт анї єдней приватней школи на руским язику анї на єдним уровню у Войводини.

Гимназия Петро Кузмяк у Руским Керестуре обезпечує подполне образованє на стредньошколским уровню на руским язику од 1970. року. То єдина стредня школа по руски на швеце. Ма интернатске змесценє за школярох и прето можлїве же би ше уписали нє лєм дзеци зоз Сербиї алє и 303 других жемох дзе жию Руснаци. Барз важне наглашиц же аж и Русини / Руснаци 303 Карпатского ареалу чувствую Гимназию як свою, окреме гевти $30 з$ України хтори нє маю скоро нїч зоз образовней вертикали яка єст у Сербиї.

Маюци у оглядзе основне и стреднє образованє, одвичательни органи 
можу допущиц виводзенє настави на руским язику (як и на язикох других националних меншинох) кед за формованє класи єст менєй од 15 школярох хтори жридлово бешеднїки. Факт же ше вкупне число школярох по класи на руским язику благо зменшує.

Оддзелєнє за русинистику на Филозофским факултету у Новим Садзе походзи од Лектората за руски язик хтори основани 1972. року (од 1981. року Катедра за руски язик и литературу) и представя найвисши уровень образованя по руски. Нови курикулум базовани на Болоньскей декларациї. Понеже руска популация у Войводини / Сербиї досц мала, Оддзелєнє за русинистику специфичне пре релативно мале число студентох. Приблїжно двацец пецеро студенти студираю на Оддзелєню, а стреднє ше уписую пецеро студенти по школским року.

Трицец пецеро студенти потераз дипломовали на Оддзелєню за русинистику. Од нїх ше обчекує же би були лидере културно-образовного живота Руснацох у Сербиї у першей половки 21. вика. Векшина 3 нїх унапрямена на язични виглєдованя.

Курси руского язика можу ше нащивйовац и на Оддзелєню за медиї дзе существує можлївосц же би ше на буджет уписали двойо студенти. Студенти зоз даскелїх оддзелєньох Филозофского факултета можу тиж студирац руски язик - як виборни.

По нєшка публиковани три руски граматики - Граматика бачваньскорускей бешеди о. др Г. Костельника (обявена 1923. року; Костельник, 1975), Граматика руского язика: Фонетика - морфология - лексика I проф. Миколи М. Кочиша (Кочиш, 1977) и Граматика руского язика проф. др Юлияна Рамача (Рамач, 2002). У перших двох, зоз двацетого вику, баржей пре дружтвенополитични условия у хторих жили авторе як пре лингвистични факти, руски язик третирани як диялект українского язика. У трецей граматики руски язик змесцени медзи заходнославянски и восточнославянски.

Автор тих шорикох, позарядови професор за предмет Руски язик на Оддзелєню за русинистику и представитель войводянских Руснацох у Интеррегионалней комисиї за кодификованє русинского язика, на числених наукових сходох ширцом швета, цо по нєшка нє була пракса, представял руски язик $з$ рижних аспектох. Проф. др Михайло Фейса бешедовал, а 
написал и даскельо статї, хтори ше директно дотикаю статуса руского язика. 3 тей нагоди пренєшем есенцию тих виглєдованьох. Увагу фокусуєм на общи фонетски и морфологийни характеристики хтори одредзую восточнославянску, заходнославянску и южнославянску язичну заєднїцу и поровнам их $3 о з$ характеристиками руского язика.

У Основох поровнуюцей траматики славянских язикох Р. Бошкович як основни характеризуюци риси славянских язичних заєднїцох видзелює шлїдуюци характеристики (Бошковић, 1977: 15-17):

А) прикмети виключно восточнославянскей язичней заєднйи̧и:

1. розвой праславянских полувокалох $b, b$ на $o$, $е$ пред праславянскима сонантами $r, l$ (русий. горло, зерно; укр. горло, зерно; руски гарло, зарно);

2. специфични розвой праславянских групох TORT, TERT, TOLT, TELT 303 ткв. восточнославянским полногласйом на TOROT, TERET, TOLOT (русий. ворона, молоко; укр. ворона, молоко; руски врана, млєко);

3. розвой праславянских групох $t j$, $d j$ на $\check{c}$, ̌̌ (укр. свіча, межа; русий. свеча, межа; руски швичка, меджа);

4. специфични розвой $е$ на початку слова хторе прешло до о (укр., русий. один, Олена; серб. јеdап, Jеlепа; руске єден, Гелена/Єлена);

Б) прикмети заходнославянскей язичней заєднӥйи:

1. розвой праславянских групох $t j, d j$ на с, $d z$ (або z) (поль. świeca, miedza; чес. svice, meze/mez; руски щвичка, меджа);

2. ̌s (а нє $s)$, як резултат другей и трецей палатализациї (чес. mouše, Čě̌ $i$, všecek; руски мухи, Чехи, ииияко);

3. одсуство такв. епентетичного л $(l)$ у суфиксалних складох (поль. zіетіа, слвц. zет; русий. и укр. земля; руски жем; русий. лублю; руски любим);

4. чуванє праславянских групох $t l$, $d l$ (укр. крило, вила/вилки; русий. крыло, виль; серб. крило, виле; слвц. kridlo, vidly; руски кридло, видли);

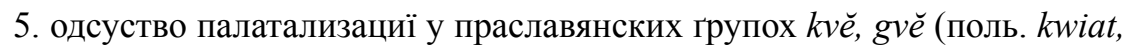
gwiazda; слвц. kvet, hviezda; укр. цзвіт/квim, звізда; русий. изветок, звезда; серб. цзвет, звезда; руске квет/квиток, гвизда).

в) прикмети южнославянскей язичней заєднӥйи:

1. прасл. $t^{\mathrm{e}}, n^{\mathrm{e}}: t e, n e ;$ т.є. праславянски палатализовани консонанти нє преходза до палаталох (серб. породити, косити, топао; укр. породити, косити, 
теплий; руски породзии, кошии, цеепли);

2. праславянски групи на початку слова ÕRT, ÕLT : RAT, LAT (раван, расти, лакат; руски ровни, роснуи, локеи);

3. праславянски групи TORT, TERT, TOLT, TELT : TRAT, TRĚT, TLAT, TLĚT (серб. врана, бр(uj)ег, мл(иј)еко; сербски тоту характеристику дзелї зоз ческим и словацким; руски врана, брег, млєко);

4. праславянске $e$ : $e$ (серб. пет, десет; русий и укр. исти: пять, десять; слвц. pet/pãt ', dzesec/desat ', вост. слвц. pejc, dzesec; руски пейu, дзешеu);

5. од праславянского $c h(h)$ достате $s$ (а нє $\check{s}$, як у заходнославянских язикох) (напр. ст. сл. Д и Л тиsӗ, vbsb; серб. муви/муси, све; чес. mouše, vše; поль. musze, zawsze; д. луж. тиг̌e, wšen; руски мухи, шицко).

Треба мац на розуме же гранїци пресцераня тих основних характеристикох трох славянских заєднїцох нє мож оштро поцагнуц. Кед бизме их сцели графично представиц, вони би нє представяли три окремни множества, алє скорей множества хторим мож, у математичней терминологиї, утвердзиц пререз. Або, як Й. Шмит, илуструюци свою теорию габи, свойочасово представел одношеня медзи индоевропскима язиками (дзе слово о штирох габох: келтскей, германскей, греческо-италскей, балто-славянско-индо-иранскей...; Ivšić, 1970: 2) як три габи хтори здабу на медзисобно споєни карики, з чим ше визначує же кажда з нїх одредзена зоз дзепоєднима заєднїцкима и дзепоєднима специфичнима прикметами.

Пререз медзи множествами найзначнєйших характеристикох южнославянскей и восточнославянскей язичней заєднйии представяю шлїдуюци характеристики:

1. прасл. групи kvĕ gvĕ : cvĕ, dzvе̌ (: zvе̌) (напр. русий. и серб. иявет, звезда, з розликами у акценту и вигваряню; руски квет/квиток, гвизда);

2 . прасл. групи $t l, d l$ зведзени на $l$ у южнославянских и восточнославянских язикох, а у заходнославянских и у руским ше затримали (русий. сало, плела, молить; серб. сало, плела, молити; слвц. sadlo, plietla, modlit; руске садло, плєтла,модлї);

3. присуство такв. епентетского л $(l)$ у суфиксалних складох (русий. земля, люблю; серб. земља, љубљен; руски жем, любим, любени).

Пререз медзи множествами найзначнєйших характеристикох 
восточнославянскей $u$ заходнославянскей язичней заєднїичи представяю шлїдуюци характеристики:

1. дакедишнє законченє -ъmь (: -om, -em) у И єдн. основох на $о$ хлопского и стреднього рода (южнославянски язики ту маю законченє -омь);

2. дакедишнє законченє -е у Г. єдн. Н и А мн. основох на $\grave{a} а$ и у А мн. основох на їо хлопского роду (южнославянски язики у тих формох дакеди мали законченє -е̨);

3. дакедишнє законченє - $a$ (южнославянски язики мали - $y$; напр. tresy) у Н єдн. партиципа презента.

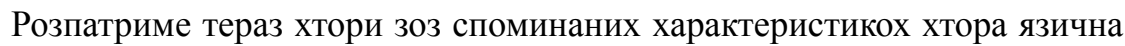
заєднїца дзелї з руским язиком. Векше або менше число прикладох, хтори превжати $30 з$ Граматики руского язика Ю. Рамача (Рамач, 2002: 501-525), на одредзени способ укаже на ступень заступеносци або одсуства одредзеней характеристики.

Характеристики хтори одредзую три язични заєднїци мож звесц на число єденац.

1. Розвой праславянских полувокалох $b, b$ пред праславянскима (носнима) вокалнима $r, l$, у руским шлїдуюци:

а) тварди полугласнїки + вокалне $р$ дали ар - гарло, кармиц, гарси, мархва, mapt-, таргац ше, карчма. Тот рефлекс обачуєме и при заходнославянских язикох, у польским. Восточнославянски рефлекс ор находзиме у горбати, запорсток и, евентуално, горди.

После $\partial, m, c$ тварди полугласнїки + вокалне $л$ дали лу напр. слунко, слуп, тлусти (коц. клусти), тлучиц, длуги. Восточнославянски рефлекс ол нє находзиме у руским язику.

б) мегки полугласнїки + вокалне $p$ тиж дали рефлекс ар кед ше находзели пред твардима консонантами $\partial, m, 3, c, л, н:$ тварди, чарнїиа, умарти, зарно, штварти, сарня, марзнуц. Алє и рефлекс ер (чернїйа, итвернїсти, мертви), хтори ше порядно зявює пред мегкима консонантами, напр. верх, верба, верции, цүерпиц, иерцуо, змеркнуц ше, иерп, червоточ, перши, червени, черпац, цуерква.

Мегки полугласнїки + вокалне л дали и рефлекс лу (тлучии, длужен) и, як у восточнославянских язикох, рефлекс ол (чолнок, полни, волна, жолти) и ов (У керест. жовти, вовк). 
Праславянски полувокали $b, b$ ше розвили на $a$ и $y$, цо заходнославянска характеристика, алє присутни и восточнославянски розвой на $o$, $e$ пред праславянскима вокалнима $r, l$, .

2. Праславянски групи TORT, TOLT, TERT, TELT дали у руским язику TRAT, TLAT, и, зоз метатезу, TRET, TLET. Восточнославянски язики характеризує полногласє, т.є. розвой на TOROT, TOLOT, TERET, TELET (напр. русий. дорога, борода, золото, болото, берег, перед, молоко, полова). Наприклад:

TRAT - брада, бразда, брана, драга, драги, ограда, гращок, заст. враг, прах, мраз, праг, крава, врана, врачии, заст. врабец, заст. врата, празни, праше, хранйи, здрави, страна, замрачии, храста, кратки, краль, трамушка, шкорванчок;

TROT (як у польским) - смрод, крот; TOROT - норов, дороги, город (представяю восточнославянски пожички);

TLAT - глад, злато, власи, глас, влакно, млаток, блато, слама, хладни, глад, глава, класка, заст. владни, влага, длань, клач, млади, плязом, платно, плашии, сладки, слани, тлачии, хлапец и др.;

TLOT (як у польским) плокаи, хлоп, млоди, млода; TOLOT - соловей (заст. славик);

TRET - брег, вред, пред, вреченко, требии, стрежии, мреи; TOROT (як у восточнославянских) черенови, чересло, черево, череп (и у польским), черешня, смерек;

ТЛЕТ - млєко, плєц, плєва.

Розвой праславянских групох вельо блїзши розвою тих групох у заходнославянских (и южнославянских) язикох.

3. Розвой праславянских групох $d j$, $t j$ шлїдуюци. Перша група $(d j)$ дала рефлекс дз (иудзи, ардза, предза, медзи) як у заходнославянских язикох, а лєм у ридких случайох обачуєме и дж (меджа, дублет беш. меджи). Друга група ( $t j)$ дала рефлекс $u$ хтори ше трима за заходнославянски (плюца, плєио) и ч хтори ше трима за восточнославянски (швичка, онучка, тисяч). Тота характеристика озда у правим смислу медзи меджами на хтори ше у литератури кладзе шветло раз як на восточнославянски, раз як на заходнославянски. Кед тоту характеристику розпатриме детальнєйше на прикладу словох меджа (слвц. medza, поль. midza, 
чес. meze/mez; укр., билорус. и русий. межа; серб. међа) и швичка (слвц. svieca/ sviečka/svička, поль. šwieca, чес. svice; укр. свіча, билорус. свеча, русий. свеча; серб. свећа), видзиме же нєт истей гласовней форми анї у єдним стандардним литературним язику двох, та и трох, славянских язичних заєднїцох. При препатраню ширшей литератури находзиме их у бешедох карпатского ареала, наволованих спрам лингвистичней ориєнтациї авторох. Напр. паралелу за меджу находзиме у атласу В. Латти як medža/međa у, як их вон наволує, українских бешедох Восточней Словацкей (Латта, 1991: К111), а паралелу за швичку находзиме у словнїку О. Р. Галаги медзи тима истима бешедами лєм же су у тим случаю наволовани восточнословацки бешеди (Halaga, 2002: II, 1003).

4. Праславянске $e$ ше на початку словох углавним очувало и гу тому опрез себе прияло консонант $\check{u}$ (такв. протетичне $\breve{u}$ ), напр. єден, єлень, єшень. Восточнославянски рефлекс присутни у словох-пожичкох озеро (заст. єзеро) и Олена (попри менох Гелена и Слена).

5. Друга палатализация, т.є. преход $k, g$, ch на $c, d z, s$ - опрез е̌, $i$ (; дифтонгского oi) у руским язику лєм часточна (дотика ше прехода $\kappa: u$; гудак : гудаци, дурак : дураии, буяк : буящи). Специфичне же $x$ нє подлєгує пременки и остава $x$ (Влахи, Чехи, кожухи) (поровнац напр. серб. Власи; укр. кожусі). Треца палатализация, т.є. преход $\mathrm{k}, g$, $c h$ на $\mathrm{c}, d z, s$ - опрез $b, i$, e подобна. Консонант $c h$ у южнославянских и восточнославянских язикох прешол до $c$, а у заходнославянских на $u$. Приклади вще и шиџко указую на векши ступень блїзкосци зоз заходнославянскима язиками (чес., слвц. vše, русий., укр. весь).

6. Одсуство такв. епентетичного $\pi(l)$ у суфиксалних складох (при йотованю $\sigma, n, 6, \phi, \mu)$ характеризує заходнославянски язики и руски язик (натопени, направени, опремени, жем, забавяи ше, явяи, любени, купя и велї други приклади).

7. Руски язик, як и заходнославянски язики, чува праславянски групи $t l, d l$; виразно очувана група $d l$ напр. видли, мидло, иидло, модліи (ше), кридло, садло, брадло, страшидло, шкерепадло, мотовидло, фуркадло, кладл-, ведл-, хтору обачуєме и у пожичкох зоз сербского мерадло, лїпкадло и латинского Русадля,; восточнославянски церковнославянски молитва, кадило и южнославянске сербске правило представяю пожички. Приклади хтори илуструю очуванє праславянскей групи $t l$ ридши, напр. гротло, плєтл-. 
8. Одсуство палатализациї (другей, постредней, прето же $\kappa, g$ нє були нєпостредно опрез $\check{e}$, алє опрез $v$ ) у праславянских групох $k v \check{e}, g v \check{e}$ характеризує заходнославянски язики и руски язик. Консонанти $\kappa, g$ ше палатализовали у восточнославянских и южнославянских язикох, а у заходнославянских су затримани (укр. цุвіт, звізда; русий. цзвет, звезда; серб. цввет, звезда; поль. kwiat, gwiazda; слвц. kvet, hviezda; рус. квет/квиток, гвизда).

9. Праславянски $t^{\mathrm{e}}, n^{\mathrm{e}}: \mathrm{t}{ }^{\mathrm{e}}, \mathrm{n}{ }^{`} \mathrm{e} ;$ т.є. праславянски палатализовани вокали у руским язику порядно преходза до палаталох, т.є. змегчую ше. Шицки праславянски палатализовани консонанти (опрез $b, i, e, \check{e}, e$ ) ше розвили до палаталох и у польским, русийским язику и, часточно, у билоруским (у 16. вику „билоруске цеканє и дзеканє”, напр. дзень, дзец̧і, цүень, цүіхі и шицки дїєслова пре инфинитивне законченє -ць: жицьь, nicau̧b, читац̧ь). У других язикох пришло до диспалатализациї, хтора подрозумює зявйованє твардих консонантох на месце дакедишнїх палатализованих консонантох у перодзе од 12. по 15. вик. Цо ше дотика руского язика, у нїм консонанти $d, t, z, s, l, n$ прешли до $\partial 3, u, \varkappa, u, ~ л ь$, нb. Вельке число прикладох илуструє тото зявенє:

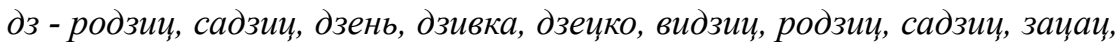
гладзиц, дзело и др. (а восточносл. дїдо, дїло, дїя; седем);

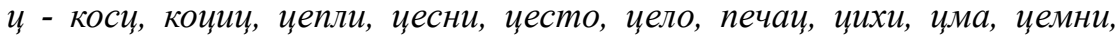

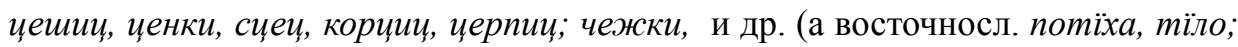
котел);

ж - жем, желєни, жец, живкац, жима и др.;

и - кошиц, мешац, мишиц, єшень, праше, иедло, иестра, иедзиц, иац, шено, шеменєц, ширка, шитко, шиви и др. (а осем, сивер, сила и весели, попри вешелє, вешелїи ше);

ль - глєдац, хлїста, глїна, хлєб, хлїв, клїтка, клїнок, клїш, приклєт, лєжаџ/лєжиц, клєчаџ/клєчиц, клєн, лїк, лєнїви, лїпа, лїсце, лєв, млїн, палєц, плєси и др. (а єлень);

нь - гнєсц, гнїв, гнїздо, гонїи, конєц, нєсц, нєвеста, нєми, нїтка, нїзки и др.

3 оглядом на палатализацию руски язик ше находзи медзи заходно(польским) и восточно- (русийски, билоруски) славянскима язиками. Значне наглашиц и то же руски язик нєдвосмислово оможлївює провадзенє очуваносци 
дакедишнього палатализованого стану.

10. Праславянска група на початку словох у руским язику ÕRT дала ROT (ровни, роснуц, робота, алє церковносл. раб), прасл. група ÕLT дала LOT (влонї, локеи) и LAT (лакомни). У сербским поряднє RAT, LAT, напр. раван, расти, лакат, лаком. Руски рефлекси маю паралели и медзи заходнославянскима и медзи восточнославянскима язиками;

11. Рефлекси прасл. е подобни восточнословацким рефлексом, з чим ше приблїжую заходнославянскей язичней заєднїци:

e найчастейше ; краткого е (пета, дзешец, месо, греда, преси, треси, мегки, дзевец, щуесие, меси, песи, праше, злєкнуи ше, чежки, жец, клєкнуц); Тот рефлекс характеристични и за сербски язик; за восточнославянски язики характеристични рефлекс $я$;

a найчастейше ; длугого еє (жаи, жадни, жадло, жадаи, часи, часто, прагаџ, зачац, вжаџ, пришага, дзешати, мешац, зацагнуи, заяц, ясна, кляц, зняц); два рефлекси вокала обачуєме и у истей основи: оглядац ше и глєдац;;

я (вязац, треца ос. мн. презента робя, любя, правя, веря); тисяч представя часц новей лексики у руским язику;

ия (пияток, пияти);

ей (пейu̧, пейдзешат).

Виводзаци заключенє по стандардних критериюмох одредзованя припадносци гу восточней, заходней и южней групи славянских язикох, мож заключиц же руски язик дзелї дакус вецей, або у векшей мири, заєднїцки характеристики 303 заходнославянскима язиками, насапредз словацким, або восточнословацкима бешедами. Место руского язика у фамелиї славянских язикох на основи виложеного мож представиц и графично: 


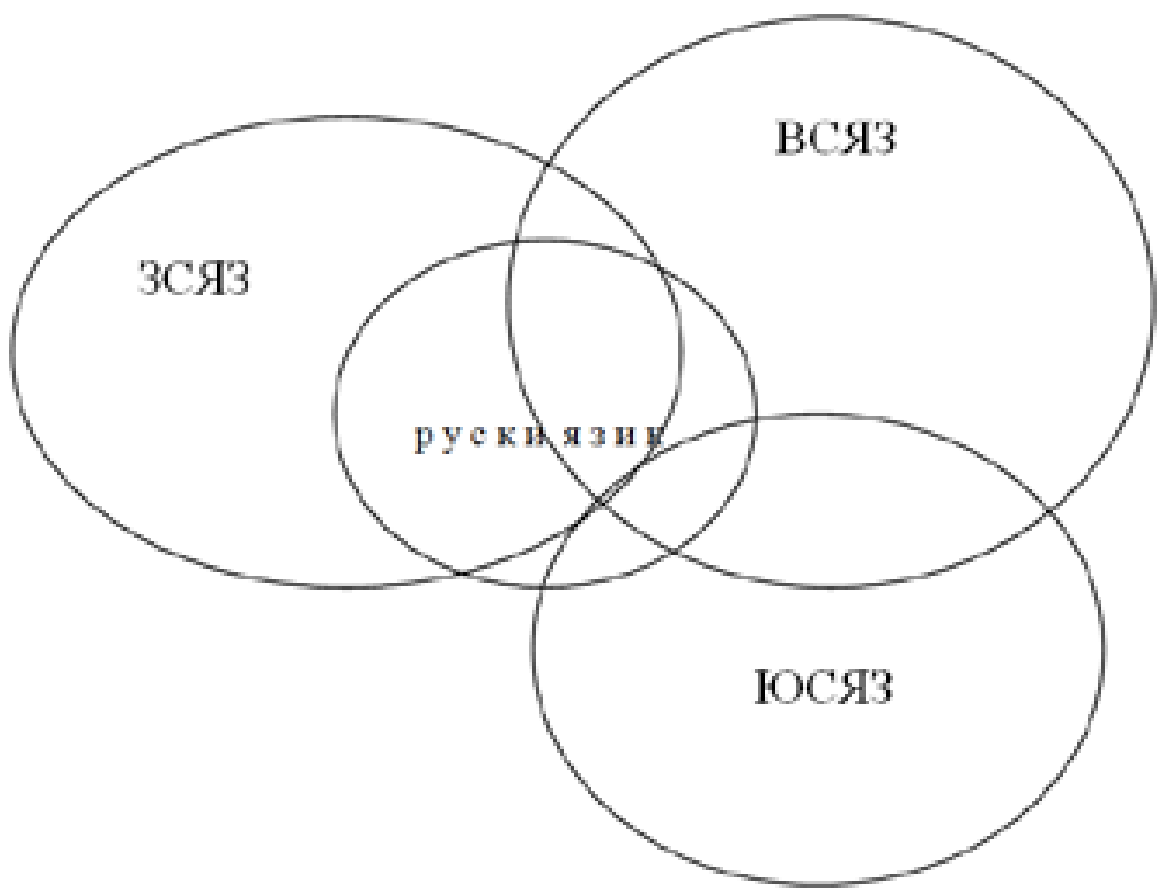

Горнє заключенє, хторе на даскельо заводи виношене на славистичних наукових сходох у жеми и иножемстве (Фейса, 2007), по нєшка нє оспорене.

До заключеня же руски язик блїзши заходнославянским язиком пришол и Вячеслав Чарский (Чарский, 2011). Вон нє провадзи традицийне поровнованє руского язика зоз стандардним словацким, польским и українским язиком, алє конструує оригиналну контактологийну методу преучованя идиома нєодредзеного походзеня у дотику зоз зроднима язиками и диялектами истей групи. Метода виробена на основи студийох америцких лингвистох Томасона и Кауфмана, русийских Иванова, Русакова, Беликова, Бернштайна и сербского контактолога Айдуковича. У корпусу своєй монографиї автор детально поровнує фонетику, лексику, морфологию, деривацию словох и синтаксу дотичних диялектох и бешедох и кажде язичне зявенє одредзує як релевантне або нєрелевантне. Кед же даєдна характеристика руского язика заєднїцка и 303 словацкима и зоз карпаторусинскима диялектами Шариша и Земплина, вец вона нєрелевантна, односно нєзначна за одредзованє походзеня руского язика. Наприклад: фиксирана наглашка на предостатнїм складу, законченє 
инструментала множини прикметнїкох -uмa, законченє першей особи множини презента-ме, формованє перфекта, потенцияла итд.; вкупно єст 18 нєрелевантни характеристики. Кед же одредзене зявенє руского язика заєднїцке з лєм єдним 303 карпатских идиомох, восточнословацким або карпаторусинским, вец воно релевантне, односно указує на походзенє руского язика. Замерковани и характеристики хтори упут`юю на восточнословацки диялект у цалосци: то рефлекси праславянского *e и праславянских групох $* t j$ и $* d j$, як и формованє императива и законченє -ом у дативу множини шицких меновнїкох итд.; вкупно 30 характеристики. Руски язик лєм 303 даєдну з восточнословацких бешедох Шариша и Земплина, а вшелїяк зоз бешедами околїска Требишова, повязую шлїдуюци характеристики: рефлекси праславянского $*_{b}$, законченє генитива шицких меновнїкох -ox, законченя - $о$ и $-y$ у дативу и локативу меновнїкох хлопского и стреднього рода, законченє -м формох першей особи єднини презента, законченє -о у номинативу множини присвойних пприкметнїкох. Вкупно осем характеристики повязую руски язик лєм зоз восточнословацкима бешедами околїска Требишова (напр. рефлекси праславянских вокалох $*_{o}>o$ и $* e>e, i, a, o, u$, пременка $s>\check{s}$ и $z>\check{z}$, та инфинитиви на -чиц итд.). Два характеристики указую лєм на шаришски бешеди Прешова (форми помоцного дїєслова буи и формованє дїєсловного прикметнїка роботного).

Пре шицко висше наведзене руски язик мож класификовац медзи восточнославянски и заходнославянски язики, або, хаснуюци у славистики существуюци термин Александра Д. Дуличенка, микроязики (Дуличенко, 2009: 8).

Зоз публикованьом монографиї Русиньскый язык главного редактора монографиї академика Пола Роберта Магочия (Magocsi, 2004) з боку Ополского универзитета у познатей сериї Сучасна история славянских язикох русински язик фактично припознати як 14. славянски язик. Руски язик третирани як єдна 303 штирох вариянтох русинского язика. Бачко-сримску вариянту русинского язика у монографиї представяю проф. др Юлиян Рамач и проф. др Михайло Фейса. Рамач литературни язик войводянских Руснацох спатрел углавним зоз морфологийного боку (Рамач, 2004), а Фейса зоз социолингвистичного аспекта (Фейса, 2004). Патраци на шветовим уровню, тому ше науковому становиску ещи 8 роки одуперала лєм политика України же би, конєчно, того року, влєце 
2012, и вона припознала науку, односно русински язик. Додайме и податок же ше русински / руски / лемковски язик находзи у вигодней ситуациї прето же ше його вариянти виучую у даскелїх русинистичних центрох - у Новим Садзе (Сербия), у Прешове (Словацка), Кракове (Польска), Нїредьгази (Мадярска), Ужгородзе (Україна) и Торонту (Канада). То по нєшка резултовало зоз организованьом даскелїх медзинародних русинистичних проєктох, а медзи нїма окреме значни проєкт хтори приведол по публикованє першей русинскей / рускей / лемковскей енциклопедиї (Magocsi, Pop, 2002).

Автор тих шорикох вообще нє песимиста у вязи зоз розвойом руского язика. Оддзелєнє за русинистику Филозофского факултета у Новим Садзе ма квалитетних и перспективних студентох. Штверо з нїх напр. активно уключени до виробку Правописного словнїка руского язика, хтори представя першу фазу виробка нового Правописа руского язика. Перши правопис, Миколи М. Кочиша, публиковани пред штирома децениями (Кочиш, 1971).

Войводянски Руснаци у Сербиї маю, праве як и други припаднїки националних меншинох, можлївосц очуваня и розвою свойого националного идентитета у обласцох гарантованих зоз Уставом и законами. Нови законски статус оможлївел рускей заєднїци основац два барз важни институциї - Национални совит рускей националней меншини и Завод за културу войводянских Руснацох. Док Завод основани за културу у найширшим смислу, Национални совит рускей националней меншини основани за штири обласци у хторих руска заєднїца ма загарантовани права - за културу, за образованє, за информованє и за урядове хаснованє язика и писма. Зоз снованьом Националного совита рускей националней меншини руска меншина ма можлївосц, з єдного боку, очувац и розвивац елементи свойого идентитета, тє. очувац и унапредзиц свойо културни, язични, вирски и други специфичносци, и, з другого боку, участвовац у дружтвеним живоце и дзелїц управну власц.

Случай руского язика хтори у урядовим хаснованю даскельо децениї, як у покраїнских органох так и на териториї шейсцох општинох у хторих Руснаци жию у значним чишлє, у каждим случаю приклад за визначованє пред велїма развитима европскима дружтвами и державами. 


\section{ЛИТЕРАТУРА}

Бошковић, Р. (1990). Основи упоредне граматике словенских језика: фонетика и морфологија. Никшић: Универзитетска ријеч.

Чарский, В. (2011). Русинский язык Сербии и Хорватии в свете языковых: лингвогенетический аспект. Щёлково: Онтопринт.

Дуличенко, А. Д. (2009).Jugoslavo Ruthenica II, Роботиз рускей филологиї и историї, Нови Сад: Филозофски факултет - Оддзелєнє за русинистику, НВУ Руске слово.

Fejsa, M. (2000). "Югославянски Русини (Руснаци) / Ruthènes de Yougoslavie / Yugoslav Rusyns (Ruthenians)" in: Multilingual European Guide of Cultural Communities and of Maisons de Pays of Europe, Le Cannet: European Federation of the Maisons de Pays, 267-278.

Фейса, М. (2004). «Социолингвистични аспект руского язика: Войводина», у: Magocsi P. R. ed., Русиньский язик. Opole: Uniwersytet Opolski, Instytut Filologii Polskiej, 373-383.

Фейса, М. (2007). “Основни характеристики руского язика у поровнаню 303 другима славянскима язиками” у: Славянские литературные микроязыки и языковые контакты, Тарту: Тартуский университет - Кафедра славянской филологии, Королевская шведская академия литературы, истории и древностей, 90-100.

Фејса, М. (2010). Нова Србија и њена русинска мањина / Нова Сербия и єй руска меншина / The New Serbia And Its Ruthenian Minority, Нови Сад: Издавачка кућа Прометеј - Културно-просветно друштво ДОК.

Gavrilović S. (1977). "Rusini u Bačkoj i Sremu od sredine XVIII do sredine XIX veka”. Godišnjak Društva istoričara Vojvodine, Novi Sad: Društvo istoričara Vojvodine.

Halaga, Ondrej R. (2002), Východnoslovenský slovnik, I-II. Košice, Prešov: Universum.

Хорњак М. (2006). “Бачко-сремски Русини” у: Фейса М. ред., Русини / Руснащи / Ruthenians (1745-2005) I, Нови Сад: ИК Прометеј - Филозофски факултет - Одсек за русинистику - КПД ДОК, 25.

Костельник, Г. (1975). Проза. Нови Сад: Руске слово. 
Кочиш, М. М. (1971). Правопис руского язика. Нови Сад: Покраїнски завод за видаванє учебнїкох.

Кочиш, М. М. (1977). Граматика руского язика: Фонетика-морфолотия - лексика I. Нови Сад: Покраїнски завод за видаванє учебнїкох.

Лабош, Ф. (1979). История Русинох Бачкей, Сриму и Славониї 17451918, Вуковар: Союз Русинох и Українцох.

Латта, Василь П. (1991). Атлас українських говорів східної Словаччини, Словацьке педагогічне видавництво, Відділ українскої літератури, БратіславаПряшев.

Magocsi, P. R. and Pop I. eds. (2002). Encyclopedia of Rusyn History and Culture. Toronto - Buffalo - London: University of Toronto Press.

Magocsi, P. R. red. (2004). Русиньскый язык. Opole: Uniwersytet Opolski - Instytut Filologii Polskej.

Рамач, Ю. (2002). Граматика руского язика. Београд: Завод за уџбенике и наставна средства.

Рамач, Ю. (2004). „Літературный язык: Войводина“, у: Magocsi P. R. ed., Русиньский язик, Opole: Uniwersytet Opolski, Instytut Filologii Polskiej, 277-304.

Руснаци у Сербиї - Информатор (2009). Руски Керестур: Национални совит рускей националней заєднїци, Завод за културу войводянских Руснацох, НВУ Руске слово

Жирош М. (1998). Бачванско-сримски Руснации дома и у швещее 17451991, II. Нови Сад: Грекокатолїцка парохия св. Павла и Петра.

Mihailo Fejsa

\section{RUTHENIAN LANGUAGE IN THE SLAVIC LINGUISTIC REGION}

\section{Summary}

The origin of the Ruthenian / Rusyn linguistic system can be traced back to the Common-Slavic period. It is a language with its own authentic and stable linguistic system. According to linguistic criteria the Ruthenian language has characteristics of mostly Western Slavic, Eastern Slavic, and even Southern Slavic languages. 
Recognized administratively in the Republic of Serbia / Autonomous Province of Vojvodina, the Ruthenian minority enjoys high degree of self-government. Legislative, executive, and judicial bodies exercise power in all areas in which the language and cultural rights of the Ruthenian minority are especially important. This applies particularly to education, culture, media, and local administration. The new legal status has enabled the Ruthenian community to establish two very important institutions - the National Council of the Rusyn National Minority and the Institute for Culture of the Vojvodinian Ruthenians.

The case of the Ruthenian language, which has been in official use for several decades both in the provincial organs and on the territory of six municipalities in which the Ruthenians live in a significant number, is by all means a prominent example for many developed European societies and states.

Key words: Ruthenians / Rusyns, Ruthenian language, minority languages, linguistic criteria.

* Робота настала як продукт проєктох 187002 и 187017, хтори финансує Министерство науки Републики Сербиї., 